大動脈血栓塞栓症の犬 4 例 の臨床症状及び

臨床病理学的所見

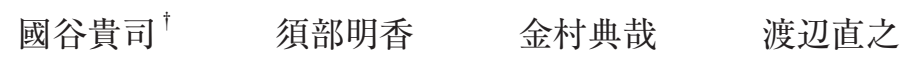

静岡県 開業（渡辺動物病院： T 427-0101 島田市大柳 825-10）

(2012 年 10 月 29 日受付 $\cdot 2013$ 年 10 月 31 日受理)

\begin{abstract}
要
約

後肢の不全麻痺を呈し，CT 検査において大動脈血栓塞栓症（ATE）と診断した犬 4 例の臨床症状と臨床病理学的所 見の特徴について検討した．初診時に跛行を呈した $11 〜 14 （ 13.0 \pm 1.4 ）$ 歳齢の高齢犬が, $14 〜 30 （ 18.0 \pm 8.0 ）$ 日 の慢性経過で不全麻痺あるいは全麻疩への臨床症状の悪化を認めた．血液検査ではD-ダイマーの上昇 (4例), AST, CK及びALTの上昇（3例)，血小板減少（3例）を認めた．慢性進行性の跛行を呈する高齢犬において，D-ダイマーの 高值がATEと関連性が高いことが示唆されたＤ－ダイマーと他の臨床検査の組み合わせにより犬のATE の診断に有 用であることが示された. ——キーワード：大動脈血栓塞栓症，D-ダイマー，犬.
\end{abstract}

-日獣会誌 $\quad 67,137 １ 41 （ 2014 ）$

大動脈血栓塞栓症 (aortic thromboembolism : ATE) は，猫に打いて比較的頻繁に遭遇する急性疾患で，激し い疼痛と後肢の麻痺を特徵とする。猫のATE は肥大型 心筋症に併発して生じることが多く，それゆえATEは 心疾患の合併症として認識される側面がある。一方，犬 におけるATEの発症はまれであり, 臨床症状, 臨床検 查所見, 治療及び予後に関する報告は少ない. 今回, わ れわれはATEと診断した犬 4 例における臨床症状と臨 床病理学的所見について, その概要を報告する.

\section{材料及び方法}

本研究は 2010 年 1 月より 2011 年 11 月までに当院を 受診し，コンピューター断層撮影 (computed tomography : CT) 検查の結果から ATE と診断した犬 4 例を 対象とした。診療記録より, 症例情報, 各種臨床検查所 見を抽出し，回顧的な調查を行った。

臨床病理学的検查として, 血液検查, 血液化学検查, また線溶系検査としてD-ダイマー及びフィブリンノフ イブリノゲン分解産物 (fibrin/fibrinogen degradation products : FDP) の各パラメータについて評価し た. D-ダイマー, FDPは, 検査機関 (三菱化学メディ エンス(侏)，東京）での外注検査にて測定を行い，血液検 查, 血液化学検查は, 全自動血球計数器 (セルタック $\alpha$, 日本光電(侏), 東京), 血液化学検査器 (ベットテス ト，アイデックス・ラボラトリーズ(侏，東京）を用いて 測定した。

画像診断として, 全例で超音波検査（LOGIQ P6, $\mathrm{GE}$ ヘルスケア・ジャパン(侏)，東京）及び C T 検査 （ECLOS，侏立メディコ，東京）を実施した。

\section{成績}

プロフィール：本症例の診断時の年齢は, $11 \sim 14$

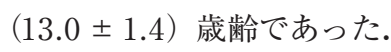

臨床症状：全例が後肢の跛行を主訴に受診し, 整形外 科的疾患あるいは脊髄疾患を疑われ，鎮痛剂の投与を受

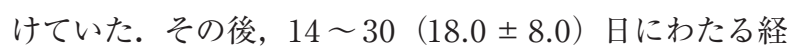
過で, 後肢症状の進行がみられた. CT 検查時に実施し た身体検查及び神経学的検查では 2 例（症例 1 及び 4 ） が全麻疩を呈し，深部痛覚の消失を認めた．2例（症例 2 及び3）は不全麻痺を認めたが，起立及び歩行は可能 であった. 3 例で触診時に後肢（症例 2 及び 3 ), 腰背部 （症例4）の疼痛を認めた。なお，大腿動脈圧は全例にお いて触知可能で，肢端の冷感，チアノーゼは確認されな かった．本症例のプロフィール，臨床症状，経過を表 1 に示した。

血液検查, 血液化学検查, 線溶系検查所見: 血液検查

$\dagger$ 連絡責任者：國谷貴司（渡辺動物病院） 于 427-0101 島田市大柳 825-10

జ0547-38-0144 FAX 0547-38-1252 E-mail : kuniya@camic.jp 
大動脈血栓塞栓症の犬 4 例の臨床症状及び臨床病理学的所見

表 1 プロフィール，症状，経過，予後

\begin{tabular}{|c|c|c|c|c|}
\hline & 症例 1 & 症例 2 & 症例 3 & 症例 4 \\
\hline 犬 種 & $\begin{array}{l}\text { キャバリア } \\
\text { K.C.スパニ } \\
\text { エル }\end{array}$ & 雑種 & 柴 & 柴 \\
\hline 年 齢 & 14歳 & 11歳 & 14歳 & 13歳 \\
\hline 性 別 & 雄 & 雄 & 雌 & 雄 \\
\hline 体 重 & $11 \mathrm{~kg}$ & $25 \mathrm{~kg}$ & $7 \mathrm{~kg}$ & $11 \mathrm{~kg}$ \\
\hline 症 状 & $\begin{array}{l}\text { 跛行 } \rightarrow \\
\text { 全麻痺 }\end{array}$ & $\begin{array}{l}\text { 跛行 } \rightarrow \\
\text { 不全麻撃 }\end{array}$ & $\begin{array}{l}\text { 跛行 } \rightarrow \\
\text { 不全麻瘒 }\end{array}$ & $\begin{array}{l}\text { 跛行 } \rightarrow \\
\text { 全麻痺 }\end{array}$ \\
\hline 経 過 & $\begin{array}{l}\text { 随意運動 } \\
\text { なし }\end{array}$ & 歩行可能 & 歩行可能 & $\begin{array}{l}\text { 随意運動 } \\
\text { なし }\end{array}$ \\
\hline $\begin{array}{l}\text { 診断まで } \\
\text { の期間 }\end{array}$ & 30日 & 14日 & 14日 & 14日 \\
\hline $\begin{array}{l}\text { 治療への } \\
\text { 反応 }\end{array}$ & $\begin{array}{c}\text { 改善 } \\
\text { 再発なし }\end{array}$ & $\begin{array}{l}\text { 改善 } \\
\text { 第 } 108 \text { 病 } \\
\text { 日に再発 }\end{array}$ & $\begin{array}{l}\text { 改善 } \\
\text { 再発なし }\end{array}$ & 反応なし \\
\hline 生存期間 & 543 日 $^{*}$ & 112 日 $^{* *}$ & 442 日 $^{*}$ & 20 日 $^{* *}$ \\
\hline
\end{tabular}

では 3 例（症例 $1 ， 2$ 及び 3$)$ で血小板数の低下（117〜 $\left.124 \times 10^{3} / \mu l\right)$ を認めた。血液化学検査では 3 例（症例 2，3 及び4）でアスパラギン酸アミノトランスフェラー ゼ (AST), クレアチンキナーゼ $(\mathrm{CK})$, アラニンアミ ノトランスフェラーゼ (ALT) の上昇を認めた。線溶系 検査では全例で $\mathrm{D}-$ ダイマーの上昇（1.93〜 7.33 $\mu \mathrm{g} / \mathrm{d} l$ )，2 例（症例 3 及び4）でFDPの上昇を認めた。 本症例の臨床病理学的所見を表 2 に示した。

超音波検査所見：腹部超音波検査では，3例（症例 1 , 3 及び4）で腹大動脈内の栓子が確認された。心エコー 検査では，症例 1 で軽度の左房拡大を認めたが，心腔内 の血栓，もやもやエコー像は確認されなかった。

CT 検査所見：造影 $\mathrm{CT}$ 検査では，3 例（症例 1,3 及 び4）で腹大動脈遠位部に栓子を認めた（図 1)。1例 （症例 2）では，腹大動脈遠位末端部で分岐した外腸骨 動脈及び内腸骨動脈内に栓子が確認された（図 2)。症 例 4 では，栓子が腎動脈分岐部まで達していた（図3）。 なお，全例で，両後肢の主幹血管内へ十分量の造影骫の 流入を認めた。

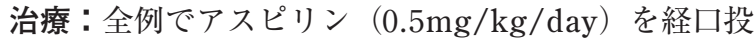
与した。

経過及び予後： 3 例（症例 1,2 及び 3 ）は，治療開始 から 7 〜 14 日後の再診時に臨床症状の改善を認めた。 症例 1 , 症例 3 は再発もみられず，現在（症例 1 ：第 543 病日，症例 3 ：第 442 病日）も生存中である。なお, 症 例 3 では治療開始後に超音波検査による栓子サイズの再 検査を実施したが，治療前と比較して明らかな変化は確 認されなかった。症例 2 は，投薬期間中（第 $1 \sim 82$ 病 日），症状の改善を認めたが，その後，投薬が中断され， 第 108 病日に後肢麻痺が再発，しぶり，血便などの消化 器症状を呈し，第 112 病日に安楽死された。臨床症状が 改善しなかった 1 例（症例 4）は，第 5 病日より骨盤周
表 2 臨床病理学的検查所見

\begin{tabular}{|c|c|c|c|c|c|}
\hline \multicolumn{2}{|c|}{ 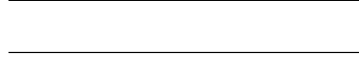 } & 症例 1 & 症例 2 & 症例 3 & 症例 4 \\
\hline \multicolumn{6}{|c|}{ 血液検査 } \\
\hline $\mathrm{RBC}$ & $\left(10^{6} / \mu l\right)$ & 5.26 & 9.13 & 9.34 & 7.9 \\
\hline $\mathrm{Hb}$ & $(\mathrm{g} / \mathrm{d} l)$ & 12.3 & 16 & 15.7 & 17.7 \\
\hline $\mathrm{MCV}$ & (fl) & 63.5 & 59 & 59.5 & 64.5 \\
\hline $\mathrm{MCHC}$ & $(\mathrm{g} / \mathrm{d} l)$ & 36.8 & 29.7 & 28.2 & 34.4 \\
\hline PCV & $(\%)$ & 37 & 47 & 49 & 51 \\
\hline $\mathrm{TP}$ & $(\mathrm{g} / \mathrm{d} l)$ & 6.8 & 6.8 & 7.8 & $\mathrm{NE}$ \\
\hline WBC & $(/ \mu l)$ & 8800 & 10500 & 15200 & 22400 \\
\hline Ban & & 87 & & 0 & 1008 \\
\hline Seg & & 6260 & & 13604 & 16128 \\
\hline Lym & & 1612 & & 1064 & 3248 \\
\hline Mon & & 656 & & 532 & 1344 \\
\hline Eos & & 138 & & 0 & 224 \\
\hline Bas & & 0 & & 0 & 0 \\
\hline \multicolumn{6}{|c|}{ Other } \\
\hline Plat & $\left(10^{3} / \mu l\right)$ & 117 & 110 & 124 & 200 \\
\hline \multicolumn{6}{|c|}{ 血液化学検査 } \\
\hline & $(\mathrm{g} / \mathrm{d} l)$ & 6.3 & 6.5 & 7.1 & 6.4 \\
\hline & $(\mathrm{g} / \mathrm{d} l)$ & 2.9 & 3.6 & 3.4 & 3.2 \\
\hline ALT & $(\mathrm{U} / l)$ & $<10$ & 248 & 403 & 588 \\
\hline AST & $(\mathrm{U} / l)$ & 10 & $>1083$ & $>1083$ & 524 \\
\hline ALP & $(\mathrm{U} / l)$ & 93 & 84 & 196 & 441 \\
\hline T-Bil & $(\mathrm{U} / l)$ & $<10$ & 0.4 & 0.8 & 0.3 \\
\hline Glu & $(\mathrm{g} / \mathrm{d} l)$ & 118 & 113 & 132 & 154 \\
\hline T-cho & $(\mathrm{g} / \mathrm{d} l)$ & 358 & 183 & 235 & 214 \\
\hline BUN & $(\mathrm{g} / \mathrm{d} l)$ & 9 & 13 & 17 & 22 \\
\hline Cre & $(\mathrm{g} / \mathrm{d} l)$ & 0.7 & 1.6 & 1.4 & 1.2 \\
\hline $\mathrm{Ca}$ & $(\mathrm{mmol} / \mathrm{d} l)$ & 9.8 & 9.2 & 9.4 & $\mathrm{NE}$ \\
\hline $\mathrm{P}$ & $(\mathrm{mmol} / \mathrm{d} l)$ & 4.6 & 3.4 & 3.9 & $\mathrm{NE}$ \\
\hline $\mathrm{Na}$ & $(\mathrm{mmol} / \mathrm{d} l)$ & 153 & 156 & 159 & 151 \\
\hline $\mathrm{K}$ & $(\mathrm{mmol} / \mathrm{d} l)$ & 4.1 & 4.3 & 4 & 4.8 \\
\hline $\mathrm{Cl}$ & $(\mathrm{mmol} / \mathrm{d} l)$ & 112 & 122 & 120 & 121 \\
\hline $\mathrm{CK}$ & $(\mathrm{U} / l)$ & $\mathrm{NE}$ & $>2036$ & $>2036$ & $>2036$ \\
\hline \multicolumn{6}{|c|}{ 線溶系検査 } \\
\hline D-ダイ & マー $(\mu \mathrm{g} / \mathrm{d} l)<1.0^{*}$ & 1.93 & 2.77 & 3.9 & 7.33 \\
\hline $\operatorname{FDP}(\mu$ & $\mathrm{g} / \mathrm{d} l)<5.0^{*}$ & $\mathrm{NE}$ & 2.8 & 16.9 & 9.4 \\
\hline
\end{tabular}

* : 参考基準值（三菱化学メデイエンス）

$\mathrm{NE}:$ not examined

囲及び両後肢に広範な皮膚壊死，壊疽がみられ，第 20 病日に安楽死された。

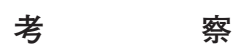

臨床の現場で遭遇する機会の多い猫のATE と比較し て, 犬のATEの発生頻度は低い. ATEと診断される犬 の割合は入院動物全体の $0.0005 \%$ という報告もあり， 過去の報告数もきわめて少ない $[1-5]$. 後肢の虚弱, 間 欠的な跛行，運動不耐性，疼痛を主徵とすることが多 く, 運動失調や, 対麻痺, 単麻痺といった神経症状を呈 することもある $[1-3]$ ．経過は，急性発症する場合と， 慢性進行性の経過が報告されているが，犬のATEでは， 診断された時点で歩行可能な症例も多く，猫のATEの 


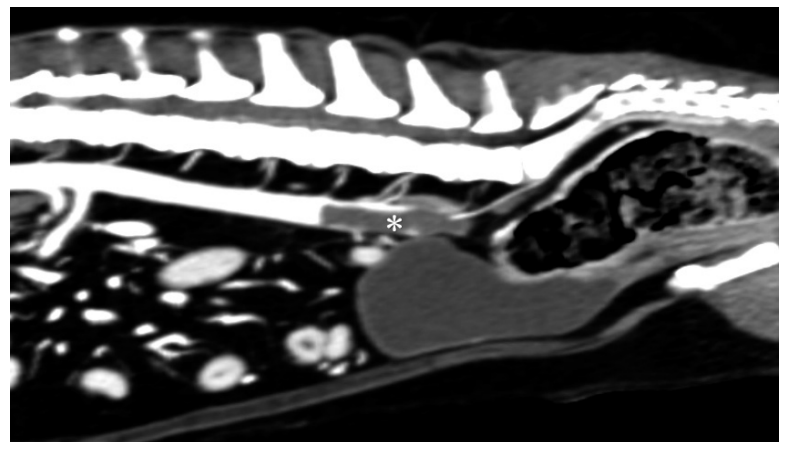

図 1 造影 CT 画像 (症例 3 , 下腹部矢状断像) 腹大動脈遠位端で内腔を占拠する栓子（*)

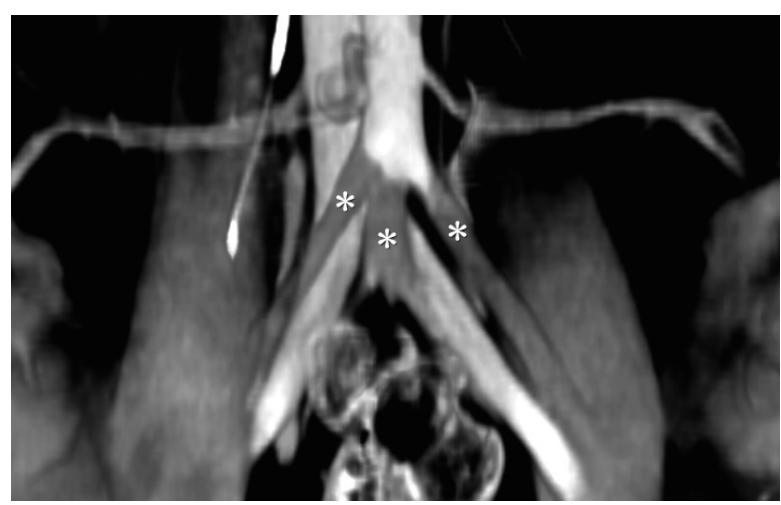

図2 造影 $\mathrm{CT}$ 画像（症例 2 , 下腹部冠状断像, スラブ厚： $10 \mathrm{~mm})$

外腸骨動脈及び内腸骨動脈に塞栓する栓子（*

臨床像とは明らかに異なる点を指摘する報告も多い［13]. 本症例の症状及び経過は, 過去の報告に一致するも のであった. 本症例では, 大腿動脈の拍動を認めたこ と, 肢端のチアノーゼや冷感がみられなかったこと, 造 影 $\mathrm{CT}$ 検查において後肢の血管内に造影剤の流入が確認 されたことからも，後肢の主幹血管における血流が維持 されていたことは明らかで, この点が, 猫の臨床症状と 異なる一因であると考えられた。

ATEの診断は，症状，身体検査，超音波検査，造影X 線検査や磁気共鳴画像 (magnetic resonance imaging : MRI）などにより行われている [3-6]. 臨床病理学的な 特徴として, AST, CK, ALT, 乳酸脱水素酵素 (LDH), 尿素窒素（BUN），クレアチニン（Cre）の上昇が報告 されている $[1,2,4]$. 本研究では, 全例で D-ダイマー の上昇， 3 例で血小板数の低下が確認された。 また，そ れぞれ3例においてAST, CK, ALTの上昇を認めた. $\mathrm{D}$-ダイマー及び血小板数の変化は体内での血栓形成を 反映したものであり，またAST，CK，ALTは筋組織か らの逸脱酵素と判断した. FDP D D ダイマーなどのフ イブリン関連マーカーは, 体内での線溶系の立進，血栓 症の除外において重要なパラメータである。 D-ダイマ 一は安定化フィブリンを含んだ血栓がプラスミンの作用

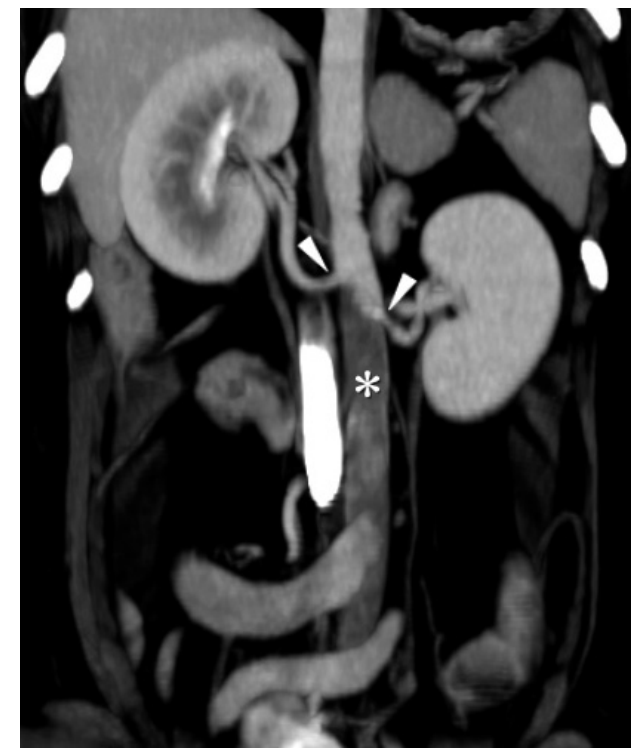

図 3 造影 $\mathrm{CT}$ 画像 (症例 4, 下腹部冠状断像, スラブ厚： $7 \mathrm{~mm}$ )

腎動脈分岐部（矢頭）まで達した腹大 動脈内の栓子（*)

により分解される過程の生成物であり，FDPにはD-ダ イマーに加えフィブリノゲンの分解産物が含まれる。フ イブリノゲンの分解が進行する線溶立進型の播種性血管 内凝固（disseminated intravascular coagulation : DIC）ではFDPの有用性が高い一方，体内ですでに確 立した血栓の証明には二次線溶のみを反映する D-ダイ マーが有用であるとされている $[7,8] . \mathrm{D}-$ ダイマーは 人の肺血栓塞栓症（pulmonary thromboembolism : PTE) や深部静脈血栓症（deep vein thrombosis DVT）のスクリーニング検査として用いられており [7]，犬のDIC P PTE などでも有用性が報告されている [2, 9-12]. また，血小板では産生低下や破壊立進によ る低下，疾患とは無関係に健康犬での低下，採血やサン プルの取り扱いによるアーチファクトでの低下が頻繁に おこる一方，D-ダイマーはアーチファクトを生じにく い点も，利点としてあげられる．以上の点から，動物医 療におけるATEを含めた血栓症でのD-ダイマーの利用 価值は高いと考えられた。本研究の結果は, 犬のATE と D-ダイマーの上昇について，強い相関性を示唆する ものであった．犬のATEにおける D-ダイマーに関する 報告はこれまでに 1 報のみで $[1]$ ，犬のATE と D-ダイ マーとの強い相関性を論じた研究は，われわれの知るか ぎり，これまでに報告されていない。臨床の現場におい て，D-ダイマーが犬の ATE の診断に利用可能であると 推測され, 今後, 症例数を重ね, 犬のATEにおける Dダイマーの特異度を検証する必要があると思われた。

犬における凝固立進，血栓形成の原因には，犬糸状虫 症，副腎皮質機能立進症，種々の腎疾患，心疾患，腫瘍 
性疾患，自己免疫疾患，DIC の他，輸血やカテーテル設 置など医原性に生じることが報告されているが，犬の ATEでは，基礎疾患が見つからないことも多い $[1-3$, 5, 6, 13-19]. 本症例でもこれらの基礎疾患は確認され ず，血栓形成の原因を明らかにすることはできなかっ た。しかしながら，慢性進行性の臨床経過から本症例の ATEの原因が，心疾患に続発する猫の病態とは異なる と考えられた。人の脳梗塞をはじめとする動脈性血栓症 では，主に頸動脈に生じる血管病変に着目されており $[20,21]$ ，全例が高齢犬であった本症例のATEにも，血 管壁に慢性的に生じた何らかの変化が関与した可能性が 推測され, 今後, 病理組織学的な検証が必要であると思 われた。

犬の血栓塞栓症における治療には，ストレプトキナー ゼやウロキナーゼ，組織プラスミノーゲン活性化因子 (tissue-plasminogen activator : t-PA）製剂などの血栓 溶解剂，アスピリン，ジピリダモールなどの血小板凝集 阻害薬，ワルファリン，ヘパリンなどの血液凝固阻害薬 などによる内科療法と，手術やバルーンカテーテルなど による外科的療法があげられる $[2,5,6,22-25]$ 。それ ぞれの治療法についての有効性を比較した詳細な研究 は，これまでに報告されておらず，現在，動物の血栓症 治療について，明確なガイドラインは存在しない. t-PA 製剂は，人の脳梗塞で用いられる非常に効果的な血栓溶 解剂である。しかしながら，梗塞により生じた血管の組 織障害により，再還流後の出血が懸念されるため，発症 から数時間以内であること，高血圧ではないことなど， 㛜密なルールのもとで使用される薬剤である $[20,26]$. 本症例は，いずれも 2 週間以上の長期経過であり，血管 壁の組織障害が危惧された。人の医療においては，動脈 血栓症の患者に対してアスピリンを中心とした血小板凝 集阻害薬が, 静脈血栓症に対しては急性例ではへパリ ン，長期投与にはワルファリンが適応されており，特に アスピリンは，さまざまな病態で広く用いられる薬剤で ある $[13,20,21,27]$. 動物医療においても，特にフィ ラリア症に対して以前より用いられている薬剤で $[2$, $24,25]$, 犬において安全に長期投与が可能なことは多 くの獣医師が経験的にも知り得ている。以上の点より, 今回われわれは犬のATEの治療としてアスピリンを選 択し，結果的に 4 例中 3 例において，アスピリンが有効 であった可能性が考えられた。

犬のATEの予後は，猫と比較して良好であると論ず る報告が多い $[3,5]$ ．急性発症した症例と慢性経過の症 例を比較した際に，慢性経過の症例が長く生存したとい う報告もある $[1,5]$ 。本研究において，超音波検査によ り栓子をモニタリングできた症例 3 では, 臨床的に十分 な改善を得られていたにも関わらず，栓子サイズは治療 前と比較して大きな変化はみられなかった。この結果
は，犬のATEにおける後肢の跛行が，腹大動脈内の栓 子そのものにより生じるのではなく，末梢に到達した血 栓による微小血管の血流障害に起因して生じている可能 性が考えられた。また，後肢の機能的な予後に関して， 腹大動脈内の血栓への介入は必ずしも必要ではないこと が示唆された。症例 4 は診断後に皮膚壊死を生じ，QOL が著しく低下，最終的に安楽死された。皮膚壊死の原因 には，血栓傾向の継続による末梢の血流障害の悪化，あ るいは腹大動脈内の栓子の増大に起因する血流量低下が 推測された。本研究では, 臨床症状, 経過と生存期間と の間に相関は認められなかったが，後肢の血流の維持が ATEの犬の短期的な生存に関する予後因子となると考 えられた。

本研究において, 犬のATEの臨床症状及び臨床病理 学的な特徴を示すことができた。犬と猫のATEは，臨 床症状，経過が異なることをわれわれ獣医師が認識し， 慢性進行性の跛行を呈する高齢犬に遭遇した際，ATE を鑑別診断に加えておくことが重要である．犬のATE の診断には各種臨床検査に加え，D-ダイマーが有用で あると考えられた，治療成績の向上や，各種疾患に続発 して発症する血栓症の予防のためには，今後，エビデン スを蓄積し，診断及び治療方法を明確に基準化すること が必要である.

症例の臨床デー夕を提供していただいた，ますだ動物クリニ ックの増田国充院長に深謝する.

\section{引 用 文 献}

[1] Lake-Bakaar GA, Johnson EG, Griffiths LG : Aortic thrombosis in dogs: 31 cases (2000-2010), J Am Vet Med Assoc, 241, 910-915 (2012)

[2] Ware WA : Thromboembolic Disease, Small Animal Internal Medicine, Nelson RW, ed, 4th ed, 192-206, Mosby Elesevier (2009)

[3] Goncalves R, Penderis J, Chang YP, Mosley J, Anderson TJ : Clinical and neurological characteristics of aortic thromboembolism in dogs, J Small Anim Pract, 49, 178-184 (2008)

[4] Brofman PJ, Thrall DE : Magnetic resonance imaging findings in a dog with caudal aortic thromboembolism and icchemic myopathy, Vet Radiol Ultrasound, 47, 334-338 (2006)

[5] Boswood A, Lamb CR, White RN : Aortic and iliac thrombosis in six dogs, J Small Anim Pract, 41, 109$114(2000)$

[6] Dunn ME : Thrombectomy and thrombolysis: the interventional radiology approach, J Vet Emerg Crit Care, 21, 144-150 (2011)

[7 ] 松本剛史, 和田英夫：DVT/PE の診断・治療マーカー (フィブリン関連マーカーを中心に)，日本血栓止血学会 誌，19，22-25(2008)

［8］林 朋恵, 朝倉英策：DIC の病態・診断, 日本血栓止血 学会誌，19，344-347 (2008) 
[9] Nelson OL, Andreasen C : The utility of plasma Ddimer to identify thromboembolic disease in dogs, $\mathrm{J}$ Vet Intern Med, 17, 830-834 (2003)

[10] Stokol T : Plasma D-dimer for the diagnosis of thromboembolic disorders in dogs, Vet Clin North Am Small Anim Pract, 33, 1419-1435 (2003)

[11] Caldin M, Furlanello T, Lubas G : Validation of an immunoturbidimetric D-dimer assay in canine citrated plasma, Vet Clin Pathol, 29, 51-54 (2000)

[12] Stokol T, Brooks MB, Erb HN, Mauldin GE : D-dimer concentrations in healthy dogs and dogs with disseminated intravascular coagulation, Am J Vet Res, 61, 393-398 (2000)

[13] Ridyard AE, Shaw DJ, Milne EM : Evaluation of platelet activation in canine immune-mediated haemolytic anaemia, J Small Anim Pract, 51, 296-304 (2010)

[14] Robert G : Pulmpnary thronboembolism, J Vet Emerg Crti Care, 19, 30-52 (2009)

[15] Wells R, Guth A, Lappin M, Dow S : Anti-endothelial cell antibodies in dogs with immune-mediated hemolytic anemia and other diseases associated with high risk of thromboembolism, J Vet Intern Med, 23, 295-300 (2009)

[16] Jacoby RC, Owings JT, Ortega T, Gosselin R, Feldman EC : Biochemical basis for the hypercoagulable state seen in Cushing syndrome, Arch Surg, 136, 1003-1007 (2001)

[17] Johnson LR, Lappin MR, Baker DC : Pulmonary thromboembolism in 29 dogs: 1985-1995, J Vet Intern Med, 13, 338-345 (1999)

[18] LaRue MJ, Murtaugh RJ : Pulmonary thromboem- bolism in dogs: 47 cases (1986-1987), J Am Vet Med Assoc, 197, 1368-1372 (1990)

[19] Schaub RG, Rawlings CA, Keith JC Jr : Platelet adhesion and myointimal proliferation in canine pulmonary arteries, Am J Pathol, 104, 13-22 (1981)

[20］内山真一郎：脳血管障害と抗血栓療法，日本血栓止血学 会誌，19，3-7 (2008)

[21］山本啓二：抗血小板療法の実際，日本血栓止血学会誌， 19, 179-182 (2008)

[22] Scott KC, Hansen BD, DeFrancesco TC : Coagulation effects of low molecular weight heparin compared with heparin in dogs considered to be at risk for clinically significant venous thrombosis, J Vet Emerg Crit Care, 19, 74-80 (2009)

[23] Bliss SP, Bliss SK, Harvey HJ : Use of recombinant tissue-plasminogen activator in a dog with chylothorax secondary to catheter-associated thrombosis of the cranial vena cava, J Am Anim Hosp Assoc, 38, 431-435 (2002)

[24] Boudreaux MK, Dillon AR, Ravis WR, Sartin EA, Spano JS : Effects of treatment with aspirin or aspirin/dipyridamole combination in heartworm-negative, heartworm-infected, and embolized heartworm-infected dogs, Am J Vet Res, 52, 1992-1999 (1991)

[25] Calvert CA, Thrall DE : Treatment of canine heartworm disease coexiting with right-side heart failure, J Am Med Assoc, 180, 1201-1203 (1982)

[26] 浦野哲盟：線溶療法の考え方と治療薬剤，日本血栓止血 学会誌，20，398-400 (2009)

[27］笠井宏樹，池田宇一：経口抗凝固薬の適正使用，日本血 栓止血学会誌，19，183-186（2008）

\title{
Clinical and Clinicopathological Findings in Four Dogs with Aortic Thromboembolism
}

\author{
Takashi KUNIYA ${ }^{\dagger}$, Asuka SUBE, Michiya KANEMURA and Naoyuki WATANABE \\ * Watanabe Animal Hospital, 825-10 Oyanagi, Shimada, 427-0101, Japan
}

\section{SUMMARY}

To describe the characteristics of clinical signs and clinicopathological findings in dogs with aortic thromboembolism (ATE), the medical records of four dogs diagnosed with ATE were reviewed retrospectively. The diagnosis of ATE was based on computed tomography (CT) imaging. Four dogs $(13.0 \pm 1.4$ years $)$ presented with evaluation of progressive paresis. All the dogs had clinical signs of pelvic limb lameness prior to presentation. The onset of clinical signs was chronic $(18.0 \pm 8.0$ days $)$ in all the dogs. Laboratory findings revealed high D-dimer concentration (four dogs), aspartate aminotransferase activity (three dogs), creatine kinase activity (three dogs), alanine aminotransferase (three dogs) and mild thrombocytopenia (three dogs). This result suggests that high D-dimer concentration is correlated with ATE in aged dogs presenting clinical signs of pelvic limb lameness with chronic onset. D-dimer combined with other clinical examinations might be useful to support the diagnosis of ATE in dogs. — Key words : aortic thromboembolism, D-dimer, dog.

$\dagger$ Correspondence to : Takashi KUNIYA (Watanabe Animal Hospital)

825-10 Oyanagi, Shimada, 427-0101, Japan

TEL 0547-38-0144 FAX 0547-38-1252 E-mail: kuniya@camic.jp 